\title{
BTTNET
}

JURNAL PENDIDIKAN TEKNOLOGI INFORMASI

http://journal.umpalangkaraya.ac.id/index.php/bitnet

Volume 4 Nomor 2, September 2019 (44-49)

\section{GLS (GERAKAN LITERASI SEKOLAH) MELALUI PENGADAAN PERPUSTAKAAN MINI DI SDN-8 MADUREJO}

GLS (School Literation Movement) Through The Procurement Of Mini Library

In SDN-8 Madurejo

Haterah

SDN 8 Madurejo, Kotawaringin Barat, Kalimantan Tengah, Indonesia

\section{ARTIKEL INFO}

Diterima

Dipublikasi

10 September 2019

\section{ABSTRAK}

Penelitian ini bertujuan untuk: (I) mengimplementasikan GSL (Gerakan Literasi Sekolah) Melalui pola perpustakaan mini. GSL (Gerakan Literasi Sekolah) Melalui pola perpustakaan mini dapat di laksanakan dengan baik. (2) untuk mengetahui apakah ada atau tidaknya peningkatan hasil belajar belajar peserta didik melalui metode problem based introduction khususnya pada tema 8 bumiku di kelas VI semester genap SD Negeri I Tempayung. Penelitian ini menggunakan metode Penelitian Tindakan Kelas.

Kata Kunci: Metode Problem Based Introduction, Tema 8 Bumiku, Hasil Belajar Tematik

\section{ABSTRACT}

This study aims to: (I) find out the learning activities of students in class $\mathrm{VI}$ in the even semester of SD Negeri I Tempayung through the problem based introduction method, especially on the 8th earth theme. (2) to find out whether or not there is an increase in student learning outcomes through the method of problem based introduction, especially on the theme of 8 earth in the sixth grade of SDN I Tempayung. This research uses the Classroom Action Research method.

Keywords: Problem Based Introduction Method, Theme 8 of Earth, Thematic Learning Outcomes

*e-mail :

Orcid : 


\section{Jurnal Pendidikan Teknologi Informasi}

\section{PENDAHULUAN}

Gerakan Literasi Sekolah adalah sebuah gerakan dalam upaya menumbuhkan budi pekerti siswa yang bertujuan agar siswa memiliki budaya membaca dan menulis sehingga tercipta pembelajaran sepanjang hayat. Kegiatan rutin ini dilaksanakan untuk menumbuhkan minat baca peserta didik serta meningkatkan keterampilan membaca. Materi baca berisi nilai-nilai budi pekerti, berupa kearifan lokal, nasional, dan global yang disampaikan sesuai tahap perkembangan peserta didik.

Minat baca merupakan salah satu kunci sukses seseorang dalam mengetahui dan menambah wawasan pengetahuannya. Kegiatan-kegiatan untuk meningkatkan minat baca harus diadakan dan digalakan. Sejalan dengan perkembangan ilmu pengetahuan dan teknologi yang semakin pesat, terutama dalam teknologi percetakan maka semakin banyak informasi yang tersimpan di dalam buku. Pada semua jenjang pendidikan, kemampuan membaca menjadi skala prioritas yang harus dikuasai siswa. Dengan membaca siswa akan memperoleh berbagai informasi yang sebelumnya belum pernah didapatkan.

Minat baca siswa dapat di tingkatkan melalui gerakan literasi sekolah. Literasi Sekolah dalam konteks GLS pada panduan gerakan Literasi Sekolah di SD adalah kemampuan mengakses, memahami, dan menggunakan sesuatu secara cerdas melalui berbagai aktivitas, antara lain membaca, melihat, menyimak, menulis, dan/atau berbicara.

Literasi sebaiknya, bukanlah sebagai hal yang musiman. Banyak kegiatan yang dilaksanakan berdasarkan proyek, dalam artian kegiatan terlaksana dengan baik selama proyek itu berlangsung, tapi pada saat proyek dan dana terhenti, kegiatanpun akan terhenti pula. Untuk meningkatkan gerakan literasi sekolah perlu perpustakaan yang menarik bagi siswa, yaitu menyediakan perpustakaan mini.
Perpustakaan mini berarti perpustakaan yang menyediakan buku dalam jumlah yang sangat terbatas.

Dalam kegiatan belajar mengajar atau proses pembelajaran terdapat faktor-faktor yang dapat mempengaruhi proses belajar siswa. Secara umum faktor-faktor tersebut dapat dibedakan menjadi dua kategori yaitu, faktor internal dan faktor eksternal.

Perpustakaan mini berarti perpustakaan yang menyediakan buku dalam jumlah yang sangat terbatas.

Darmono mengemukakan bahwa Perpustakaan pada hakekatnya adalah pusat sumber belajar dan sumber informasi bagi pemakainya. Perpustakaan dapat pula diartikan sebagai tempat kumpulan buku-buku atau tempat buku-buku dihimpun dan diorganisasikan sebagai media belajar siswa.

Pengertian perpustakaan adalah kumpulan bahan informasi yang terdiri dari bahan buku/book materials dan bahan nonbuku/nonbook materials yang disusun dengan sistem tertentu dipersiapkan untuk diambil manfaatnya/pengertiannya, tidak untuk dimiliki sebagian maupun keseluruhan. Ibnu Ahmad Saleh memberikan definisi perpustakaan adalah tempat pengumpulan pustaka atau kumpulan pustaka yang diatur dan disusun dengan sistem tertentu, sehingga sewaktu-waktu diperlukan dapat ditemukan dengan mudah dan cepat.

Tujuan perpustakaan tidak dapat lepas dari fungsi perpustakaan. Diantara tujuan pokok didirikannya sebuah perpustakaan adalah :

a. Menyediakan sarana atau tempat untuk menghimpun berbagai sumber informasi untuk dikoleksi secara terus menerus, diolah dan diproses.

b. Sebagai sarana atau wahana untuk melestarikan hasil budaya manusia (ilmu pengetahuan, teknologi dan budaya) melalui aktifitas pemeliharaan dan pengawetan koleksi. 


\section{Jurnal Pendidikan Teknologi Informasi}

c. Sebagai agen perubahan (Agent of changes) dan agen kebudayaan serta pusat informasi dan sumber belajar mengenai masa lalu, sekarang, dan masa akan datang. Selain itu, juga dapat menjadi pusat penelitian, rekreasi dan aktifitas ilmiah lainnya.

d. Menciptakan budaya membaca untuk mencerahkan masa depan bangsa. Karena dari membaca inilah kita dapat memperoleh berbagai macam pengetahuan yang berguna untuk menjadi bekal di kehidupan kita yang akan datang.

\section{METODOLOGI PENELITIAN}

Penelitian ini dilaksanakan di SDN-8 Madurejo dengan subjek penelitian adalah guru kelas dan guru mata pelajaran yang ada di sekolah dasar ini, baik yang sudah pegawai negeri sipil maupun yang masih wiyata bakti. Jumlah seluruh dewan guru yang menjadi subyek penelitian adalah adalah 9 orang.

Kondisi di sekolah binaan belum ada GSL (Gerakan Literasi Sekolah), makanya peneliti hendak mengimplementasikan GSL (Gerakan Literasi Sekolah) di sekolah binaan peneliti.

Penelitian ini dilaksanakan di SDN-8 Madurejo dengan subjek penelitian adalah guru kelas dan guru mata pelajaran yang ada di sekolah dasar ini, baik yang sudah pegawai negeri sipil maupun yang masih wiyata bakti. Jumlah seluruh dewan guru yang menjadi subyek penelitian adalah adalah 9 orang.

Kondisi di sekolah binaan belum ada GSL (Gerakan Literasi Sekolah), makanya peneliti hendak mengimplementasikan GSL (Gerakan Literasi Sekolah) di sekolah binaan peneliti.

I. Siklus I

Pada tahap perencanaan peneliti merumuskan dan mempersiapkan: rencana jadwal pelaksanaan tindakan, rencana pelaksanaan pembinaan kedisiplinan, membuat lembar observasi, dan mempersiapkan kelengkapan lain yang diperlukan dalam rangka analisis data. Pelaksanaan pembinaan kedisiplinan Siklus I dilaksanakan selama I X pertemuan dalam seminggu. Pelaksanaan tindakan pada dasarnya disesuaikan dengan setting tindakan yang telah ditetapkan dalam rencana pelaksanaan. Setelah proses bembinaan GSL (Gerakan Literasi Sekolah) selesai maka dilakukan pengamatan selama seminggu terhadap sekolah. Pengamatan dilakukan untuk mengetahui implementasi GSL (Gerakan Literasi Sekolah).

2. Siklus II

Pada tahap perencanaan peneliti merumuskan dan mempersiapkan melakukan tindak lanjut siklus I, yaitu dalam siklus II dilakukan perbaikan. Peneliti yang dalam hal ini adalah pengawas Sekolah mencari kekurangan dan kelebihan mengetahui implementasi GSL (Gerakan Literasi Sekolah) Melalui pola perpustakaan mini. Kelebihan yang ada pada siklus I dipertahankan pada siklus II, sedangkan kekurangannya diperbaiki. Peneliti menyiapkan lembar evaluasi (penilaian), lembar observasi untuk mengetahui implementasi GSL (Gerakan Literasi Sekolah) Melalui pola perpustakaan mini. Pelaksanaan Siklus II juga dilaksanakan I kali selama seminggu. Proses tindakan pada siklus II dengan melaksanakan program bembinaan kediplinan berdasarkan pada pengalaman hasil dari siklus I. Dalam tahap ini peneliti melaksanakan metode yang diterapkan berdasarkan Tindakan pada siklus I, perbedaannya adalah pada siklus II dilaksanakan dengan pengontrolan implementasi GSL (Gerakan Literasi Sekolah) Melalui pola perpustakaan mini. Setelah proses bembinaan kedisiplinan selesai maka dilakukan pengamatan selama seminggu terhadap implementasi GSL (Gerakan Literasi Sekolah). Pengamatan dilakukan untuk mengetahui implementasi GSL (Gerakan Literasi Sekolah) Melalui pola perpustakaan mini. Adapun yang di amati pada siklus 2 sama dengan yang diamati pada siklus I. 


\section{Jurnal Pendidikan Teknologi Informasi}

Agar pelaksanaan pembinaan kedisiplinan yang dilakukan dapat berjalan dengan baik, peneliti mengadakan pengamatan langsung terhadap GSL (Gerakan Literasi Sekolah) Melalui pola perpustakaan mini.

Teknik pengumpulan data memiliki peranan penting, hal tersebut disebabkan karena pemerolehan data dalam sebuah penelitian akan dijadikan sebagai bahan dan bukti untuk dijadikan sebagai pegangan dalam melakukan penilaian. Suharsimi Arikunto (2008: I50-158) menyebutkan bahwa "Jenis metode pengumpulan data terdiri dari tes, angket atau kuesioner, interview, observasi, skala bertingkat, dan dokumentasi”.

\section{HASIL DAN PEMBAHASAN}

I. Pesiapan sebelum penelitian

Peneliti mengadakan beberapa persiapan yang diperlukan sebelum pelaksanaan penelitian. Adapun persiapan yang peneliti lakukan sebelum penelitian adalah sebagai berikut:

a. Melakukan observasi awal untuk mengidentifikasi masalah melalui wawancara dengan guru di SDN-8 Madurejo

b. Peneliti meminta persetujuan izin riset

c. Melakukan observasi lanjutan untuk mencari informasi tentang GSL (Gerakan Literasi Sekolah).

\section{Siklus I}

Implementasi gerakan literasi yang ada di SDN-8 Madurejo yaitu mengacu penuh pada buku pedoman yang diterbitkan oleh kementerian pendidikan dan kebudayaan (kemendikbud). Buku yang berjudul gerakan literasi sekolah yang ada disekolah tersebut didapat melalui fasilitas internet dengan cara mendownload sendiri, sebab kemendikbud tidak mendistribusikan buku panduan literasi yang diterbitkanya secara langsung kesekolahsekolah.

Adapun dalam pelaksanaan kegiatan gerakan literasi SDN-8 Madurejo, sekolah ini memiliki srtuktur penanggung jawab yang diketuai oleh kepala yang bertugas megawasi serta mejadikan motor atau penggerak utama jalanya kegiatan literasi SDN-8 Madurejo. Perpustakaan mini di sekolah menjadi media pendukung utama sebab di dalam perpustakaan terdapat berbagai sumber ilmu serta informasi yang bisa dengan mudah didapat oleh warga sekolah yaitu dengan membaca koleksi buku-buku yang ada. Berikut adalah tahapan proses impelentasi gerakan literasi yang ada di sekolah SDN-8 Madurejo:

a. Persiapan gerakan literasi sekolah

b. Pelaksanaan Gerakan Literasi Sekolah

c. Observasi

Hasil dari observasi siklus I adalah Ada perpustakaan mini di setiap kelas, Terdapat buku-buku dalam perpustakaan mini di setiap kelas, Siswa melaksanakan gerakan literasi sebelum memulai pelajaran, Guru membimbing siswa melaksanakan gerakan literasi, Sekolah menfasilitasi buku-buku untuk di jadikan koleksi di perpustakaan mini. Artinya Gerakan Literasi Sekolah melalui perpustakaan mini di SDN-8 Madurejo sudah bagus.

3. Siklus II

Implementasi gerakan literasi yang ada di SDN-8 Madurejo, seperti yang peneliti amati dari mengikuti kegiatan literasi secara langsung ataupun menganalisa hasil wawancara dari berbagai pihak, maka gerakan literasi yang ada di sekolah ini sudah sampai kepada tahap pembelajaran. Mengingat pada prinsipnya kegiatan literasi pada tahap pembiasaan sama dengan tahap pengembangan. Yang membedakan adalah bahwa kegiatan 15 menit membaca baik didalam hati ataupun secara nyaring diikuti tindakan lanjut pada tahap pengembangan.

Implementasi gerakan literasi sekolah yang ada di SDN-8 Madurejo sampai kepada tiga tahap yaitu: tahap pembiasaan yaitu menumbuhkan minat baca melalui 15 menit membaca buku non pelajaran, Tahap pengembangan yaitu siswa menganalisis atau 


\section{Jurnal Pendidikan Teknologi Informasi}

menceritakan kembali buku yang telah mereka baca dengan cara story map atau diskusi buku. Tahap pembelajaran yaitu menanggapi teks buku bacaan pengayaan dan buku pelajaran seperti bahasa indonesia, matematika, agama dsb. Faktor-faktor pendukung dan penghambat gerakan literasi sekolah yang ada di SDN-8 Madurejo antara lain yaitu: Sarana dan prasarana sekolah yang memadai seperti adanya pojok perpustakaan di tiap-tiap kelas yang sudah disediakan disekolah, speaker pengeras suara, ketersedian buku yang lengkap, adanya program sumbangan buku bagi orang tua pada saat kenaikan kelas dengan sukarela, sumbangan buku dari guru secara pribadi dan sukarela kepada sekolah, program sumbangan buku dari alumni SDN-8 Madurejo melalui media sosial seperti facebook menjadikan beberapa program di atas memperkaya jumlah buku yang ada di perpus sekolah, Adanya tim booklovers yang membantu kegiatan literasi yang ada di sekolah.

Faktor penghambat yaitu: adanya kegiatan diluar jam skegiatan belajar mengajar seperti halnya rapat sekolah, yang menjadikan kegiatan literasi sekolah terganggu dan ditiadakan, kurangnya minat baca siswa, kurangnya motivasi guru agar menjadikan siswa gemar membaca, kondisi kelas yang tidak kondusif saat diadakanya kegiatan literasi.

Solusi gerakan literasi sekolah yang ada di SDN-8 Madurejo yaitu Memotivasi siswa agar terus memiliki semangat dalam mengikuti kegiatan literasi sekolah, Memberikan arahan atau teguran kepada siswa apabila tidak mengikuti kegiatan literasi sekolah dengan baik, Menghimbau kepada seluruh warga sekolah baik guru ataupun siswa untuk gemar membaca dan menullis agar menjadi pribadi yang literat, menjaga kebersihan lingkungan sekolah agar kegiatan literasi yang ada disekolah dapat berjalan dengan nyaman.

\section{KESIMPULAN}

Adapun dalam pelaksanaan kegiatan gerakan literasi SDN-8 Madurejo, sekolah ini memiliki srtuktur penanggung jawab yang diketuai oleh kepala yang bertugas megawasi serta mejadikan motor atau penggerak utama jalanya kegiatan literasi SDN-8 Madurejo. Perpustakaan mini di sekolah menjadi media pendukung utama sebab di dalam perpustakaan terdapat berbagai sumber ilmu serta informasi yang bisa dengan mudah didapat oleh warga sekolah yaitu dengan membaca koleksi buku-buku yang ada. Tentu saja kesadaran dari warga sekolah sendirilah yang menjadi poin penting terlaksananya gerakan literasi yang baik dan menjadikan warga sekolah menjadi pribadi yang literat.

Faktor-faktor pendukung dan penghambat gerakan literasi sekolah yang ada di SDN-8 Madurejo antara lain yaitu: Sarana dan prasarana sekolah yang memadai seperti adanya pojok perpustakaan di tiap-tiap kelas yang sudah disediakan disekolah, speaker pengeras suara, ketersedian buku yang lengkap, adanya program sumbangan buku bagi orang tua pada saat kenaikan kelas dengan sukarela, sumbangan buku dari guru secara pribadi dan sukarela kepada sekolah, program sumbangan buku dari alumni SDN-8 Madurejo melalui media sosial seperti facebook menjadikan beberapa program di atas memperkaya jumlah buku yang ada di perpus sekolah, Adanya tim booklovers yang membantu kegiatan literasi yang ada di sekolah.

Faktor penghambat yaitu: adanya kegiatan diluar jam skegiatan belajar mengajar seperti halnya rapat sekolah, yang menjadikan kegiatan literasi sekolah terganggu dan ditiadakan, kurangnya minat baca siswa, kurangnya motivasi guru agar menjadikan siswa gemar membaca, kondisi kelas yang tidak kondusif saat diadakanya kegiatan literasi. 


\section{Jurnal Pendidikan Teknologi Informasi}

Solusi gerakan literasi sekolah yang ada di SDN-8 Madurejo yaitu Memotivasi siswa agar terus memiliki semangat dalam mengikuti kegiatan literasi sekolah, Memberikan arahan atau teguran kepada siswa apabila tidak mengikuti kegiatan literasi sekolah dengan baik, Menghimbau kepada seluruh warga sekolah baik guru ataupun siswa untuk gemar membaca dan menulis agar menjadi pribadi yang literat, menjaga kebersihan lingkungan sekolah agar kegiatan literasi yang ada disekolah dapat berjalan dengan nyaman.

Berdasarkan kesimpulan dari penelitian, maka penulis pada bagian ini mengemukakan saran kepada:

a) Menjalankan peran dan tugasnya dengan baik sebagai kepala sekolah dan melaksanakan program pendidikan sesuai dengan amanah nasional serta melaksanakan programprogram pemerintahan seperti kegiatan literasi sekolah dengan lebih baik.

b) Menjaga StakeHolder di lingkungan SDN-8 Madurejo agar tercipta suasana belajar yang kondusif dan perkembangan lembaga pendidikan yang di pimpinnya bisa terus maju dan selaras sesuai dengan cita-cita bangsa.

2. Kepada seluruh guru yang ada di SDN-8 Madurejo, untuk selalu memberotivasi kepada siswa agar dapat menjalankan kegiatan literasi sekolah dengan baik, sehingga siswa dapat menjadi pribadi literat.

3. Kepada seluruh siswa dan siswi SDN-8 Madurejo agar memiliki semangat yang tinggi dalam menuntut ilmu, dan mengikuti semua kegiatan yang ada di sekolah dengan baik.

\section{DAFTAR PUSTAKA}

Abin Syamsudin. 2009. Psikologi Kependidikan. Bandung : PT. Remaja Rosdakarya.

Anselm,dkk, Dasar-dasar Penelitian Kualitatif (Prosedur, Tehnik danTeori Grounded), 1997. Penyadur Junaidi Ghony, PT Bina Ilmu, hlm. II.
Arikunto, Suharsimi, 2010. Prosedur Penelitian Suatu Pendekatan Praktek, Jakarta: Penerbit Rineka Cipta.

Bungin, Burhan, 2003. Analisis Data Penelitian Kualitatif, Jakarta: PT Rajagrafindo Persada.

Bungin, Burhan, 2007. Penelitian Kualitatif: Komunikasi, Ekonomi, Kebijakan Publik, dan IImu Sosial, Jakarta: Kencana Prenama Media Group.

http://carapedia.com/model_pembelajaran_jig saw_info587.html : Diakses pada tanggal $07 \quad$ Maret 2012 http://infoini.com/20I/pengertianmetode-jigsaw.html : Diakses pada tanggal 07 Maret 2012 Silberman, Mel. 2010. Cara Pelatihan \& Pembelajaran Aktif. Jakarta: PT Indeks.

Muhibin Syah.(2004).Psikologi Pendidikan Dengan Pendekatan Baru. Bandung: PT.Remaja Rosda karya.

Purwanto, M. Ngalim. 200I. Prinsip-Prinsip dan Teknik Evaluasi Pengajaran, Bandung: PT. Remaja Rosdakarya.

Suryabrata, Sumardi. 2002. Psikologi Pendidikan, Jakarta: PT. Raja Grafindi Persada.

Soedarsono, F.X, AplikasiPenelitian Tindakan Kelas. Departemen Pendidikan Nasional, hlm. 2.

www.kabarpendidikan.blogspot.com,www.ar minaperdana.blogspot.com,www.kmpm alang.com : Diakses pada tanggal 07 Maret 2012 .

Zaini, Hisyam dkk. Strategi Pembelajaran Aktif. Yogyakarta : Pustaka Insan Madani, 2006 http:///sunartombs.wordpress.com/200 9/06/15/pengertian-dan-penerapanmetode-jigsaw: Diakses pada tanggal 07 Maret 2012. 